\title{
Consequences of High Population in Teaching and Learning of Computer Courses in Kwara State College of Education, Oro
}

\author{
Madandola Tajudeen Niyi ${ }^{1}$, Sakariyau Sherif Niyi ${ }^{2}$, Salawu Omotayo ${ }^{3}$, Boye Eni Tina \\ M.O ${ }^{4}$, Jimoh Ruth Olubukola ${ }^{5}$, Junaidi Salat ${ }^{6}$ \\ 1,2,3,4,5 Department of Computer Science, Kwara State College of Education, Oro, Nigeria \\ ${ }^{6}$ Jabal Ghafur University, Indonesia \\ nmadandola@yahoo.com
}

\begin{abstract}
The study scrutinised consequences of high population in teaching and learning of computer courses in Kwara State College of Education, Oro. The population for this study consisted of one hundred and twenty students of department of Computer Science, Kwara State College of Education Oro. Female students participated more in the study than the male students. Students between age brackets of $21-25$ years have the highest frequency of respondents. Structured questionnaire was designed and used to collect data. The data gathered in section A of the questionnaire was analysed with frequency count and bar chart. The three formulated and tested alternative hypotheses were analysed with chi square statistical tool and all the three were accepted. The study exposed the negative consequences of overpopulated class in teaching and learning of computer courses.
\end{abstract}

Keywords

learning; teaching; computer course; frequency count; overpopulation

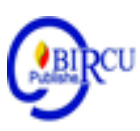

\section{Introduction}

The world advancement and sovereignty hangs on qualitative education. Educational planning in any nation has always beyond the financial capacity of the government (Adesina, 2000). Tanwa (2007) observed that environment is one of the rudimentary factors that influences way of life in any society. An environment performs a cogent role in the academic performance and health well-being of a man. The learner population and its arrangement in academic environment contributed greatly to academic performance of the learners. Human resources (HR) has a significant role in every activity in an institution including educational institutions (Tanjung, 2020). Countries in which women are better educated typically have smaller families and lower rates of population growth (stateuniversity.com: 2327).

Banji (2005) opined that the population of an environment could be positively or negatively determined by early marriage, late marriage, death rate, wars, national disaster, and climatic condition. The world is with current population of over 7.6 billion people and growing, it could reach 8 billion by 2025, 9 billion by 2040, and a whopping 11 billion by 2100 because it is growing rapidly (LeBlanc, 2018). Dr. Banji classified population into two which are under population and over population.

High population also referred to as over population in academic environment is when the number of learner is more than a few resources for their survival (Tanwa, 2007). Also, Agu (2007) referred to over population as a situation where the total number of people in an area excels the available resources. The people have limited resources to compete for and their standard of living is very low generally, thus will in turn increase the cost of living. Furthermore, Osuji (2008) defined overpopulation as shortage in resources development in 
relation to the accessible student. The implication is that the available resources is inadequate for the current number of student. High population is one of the major noteworthy problems confronting academic environments and teachers in the world today (Hussein and Mayor, 2019). Schools with high population is liable to experience difficulties, as a result of the total number of students that is more than current resources. Earthman (2002) claimed student requires a noiseless environment to attain quality learning and be able to hear clearly and understand what was being spoken. The obstructing constituent is that the infrastructure amenities are inadequate for learning due to the large number of students who need conducive learning places (Siregar, Mesiono and Salamuddin, 2020). Overpopulation is associated with negative environmental and economic outcomes ranging from the impacts of over-farming, deforestation, and water pollution to eutrophication and global warming (LeBlanc, 2018).

This study examined the consequences of high population over the teaching and learning of the computer courses in Kwara State College of Education Oro. It focused on usage relationship between the population of admitted students in the department and the available resources. Kwara State College of Education Oro which was established mainly to prepare and produce the much needed middle level man power qualitative education to pupils in the primary schools and at the junior secondary school levels in the State. One hundred and twenty students were selected at random from department of computer science to form the population for the research. Forty-five (45) students in NCE III, forty (40) in NCE II and thirty-five (35) students in NCE I were selected. The study revealed that high population has negative consequence over the learning and teaching of computer courses in Kwara State College of Education Oro.

The population of students in schools is vastly increasing for the past two decades causing over population in the college. The irony part of it is that there is decline in available resources without or with meagre provision of new facilities, infrastructures, teachers and so on. The rate of decline in quality of education resulted in the study of consequences of high population on teaching and learning of computer courses in Kwara State College of Education Oro.

The study provides answer to the following questions:

1. How does high population affect the students learning situation?

2. What are the problems faced by the lecturers as a result of high population of students in computer courses?

3. Is it necessary to reduce student population by the school management?

4. Are the laboratory facilities adequate?

Three alternative research hypotheses were formulated. They are:

Hil: There is wide ratio between population of students offering computer courses in KWCOED Oro and number of their lecturers.

Hi2: Overpopulated computer courses lecture room has significant impact on academic performance of students.

Hi3: Controlling Computer Students Population has influence in Kwara State College of Education Oro.

The study focused on consequences of high population of teaching and learning of computer courses only and using Kwara State College of Education Oro only as a case of study. The research result from this college can be generalized to solve similar problem existing in other areas of high population in teaching and learning on computer courses. 


\section{Review of Literatures}

Hasan Merza, the executive director of the World Bank (WB) Group in Washington, DC, whispered that the actual problem before the Egyptian economy at the present-day is overpopulation, remarking that Egypt's population raises by $2.3 \%$ yearly, which could destroy any economic development. "When the population is huge, this makes it unbreakable for the economy to attain the favourite growth". He identified further that another challenge economic growth in the Arab region is encountering is education. The Arab world does not only need education, but rather a revolution in the field, as there is no agreement between education and jobs, and as education years escalate, obtaining a job becomes tougher as a consequence of overpopulation (Kamel, April 6, 2019).

Olaleye, Ajayi, Oyebola and Ajayi (2017) study publicized that $97.3 \%$ of the sample population were of the view that there was inadequate of infrastructural facilities as a result of high population in lecture-rooms. The study also shown that high population in lectureroom meaningfully contributed to behavioral attitude of students studies. It also showed that overcrowding of classrooms significantly affect effective teaching and learning. The study concluded that overcrowding of classroom had significantly influence on student's behavioral attitude of students to their studies.

Khan and Iqbal (2012) argued that school facilities affect student academic achievement. The study observed that the current issue of large class size experienced by many town schools, student learning and academic performance is under challenge. Researchers showed that shortage of learning material was common in schools with large class size.

Abimbola (2005) concluded that, despite the fact that high population is having a role to play in the academic and economic situation of a school, it is better to maintain minimum or low population, for proper managing of resources. It was observed that high population led to increase in government expenditure, the government would spend more on economic and social service like crime prevention, health hazard and so on.

Oludare (2003) said that high population in our tertiary institution makes life to be risky. The attitude of students towards crime is increasing as a result. Such of that crime identified was examination malpractice. When the classes were congested or overcrowded the students found it difficult to hear clearly what the lecturer was teaching and students look for other means of excelling in their examination. The more the population goes up the high the rate of stubborn students admitted to the school. It had negative impact of education on students and lecturer.

Green and Doran (2000) said overcrowded classroom caused shortage of instrument materials, inadequate school library collection and limited storage space for learning resources. Student attending schools with insufficient learning material are handicapped in their academic achievement.

Johnson (1995) observed that large or high population led to congestion. The congestion caused inability to control the student by their teachers, disorderliness in classroom which resulted in failure of many students. Also, a classroom situation that is highly congested lack good ventilation and assist easy transmission of some communicable disease which can play a negative achievement. 


\section{Research Methods}

\subsection{Research Design}

The study utilized questionnaire to acquire information from students of Department Computer Science of Kwara State College of Education, Oro.

\subsection{Target Population}

The target populations for this study are students of Department Computer Science of Kwara State College of Education, Oro. One hundred and twenty students were selected at random from the department in which forty-five (45) students in NCE III, forty (40) in NCE II and thirty-five (35) students in NCE I were selected.

\subsection{Instrumentation}

Structured items questionnaire was employed to gather data from the 120 respondents. It was divided to section A and B. Section A is the personal data of the respondents while section B was about the study with the prepared questions. The questionnaire was developed based on the research questions. Again, a close format questionnaire with Agree (A) and Disagree (D) type of questionnaire was used.

\subsection{Method of Data Analysis}

The method employed in analysing the data involves computing the frequencies of the respondent's answers and analysed using bar chart. The three alternative hypotheses formulated were tested with the Chi square statistical tool.

\section{Discussion}

The findings were hereby presented below:

Seventy (70) females and fifty (50) males were selected at random as respondents that participated in the study.

Table 1. Gender Distribution of Respondent

\begin{tabular}{|c|c|c|}
\hline Sex & $\begin{array}{c}\text { No of } \\
\text { Respondents }\end{array}$ & $\begin{array}{c}\text { Percentage } \\
(\boldsymbol{\%})\end{array}$ \\
\hline Male & 50 & 41.67 \\
\hline Female & 70 & 58.33 \\
\hline Total & $\mathbf{1 2 0}$ & $\mathbf{1 0 0 . 0 0}$ \\
\hline
\end{tabular}

(Source: Field Survey (April 2020)) 


\section{Gender Distribution}

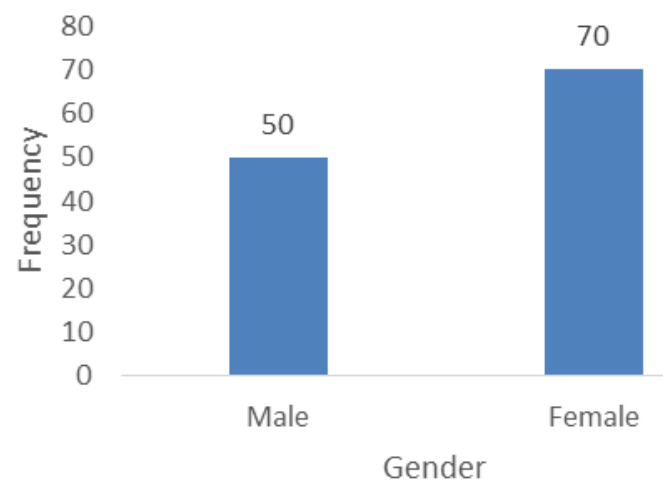

Chart 1. Gender Distribution of Respondents (Source: Field Survey (April 2020))

Table 1 and Chart 1 showed the gender frequency distribution of respondents in which $58.33 \%$ of female students participated against $41.67 \%$ of male students who participated as respondents. This shows that more female students participated than male students in the study area.

Table 2. Age Distribution of Respondents

\begin{tabular}{|c|c|c|c|c|c|}
\hline \multirow{2}{*}{ Age } & \multicolumn{4}{|c|}{ No of Respondents } & Percentage \\
\cline { 2 - 5 } & $\begin{array}{c}\text { NCE } \\
\text { I }\end{array}$ & $\begin{array}{c}\text { NCE } \\
\text { II }\end{array}$ & $\begin{array}{c}\text { NCE } \\
\text { III }\end{array}$ & Total & (\%) \\
\hline $\begin{array}{c}\text { 15 years and } \\
\text { below }\end{array}$ & - & - & - & 0 & - \\
\hline 16 - 20 years & 24 & 13 & 02 & 39 & $32.50 \%$ \\
\hline 21-25years & 09 & 26 & 32 & 67 & $55.83 \%$ \\
\hline $\begin{array}{c}\text { 26 years and } \\
\text { above }\end{array}$ & 2 & 1 & 11 & 14 & $11.67 \%$ \\
\hline Total & $\mathbf{3 5}$ & $\mathbf{4 0}$ & $\mathbf{4 5}$ & $\mathbf{1 2 0}$ & $\mathbf{1 0 0 . 0 0 \%}$ \\
\hline
\end{tabular}

Source: Field Survey (April 2020) 


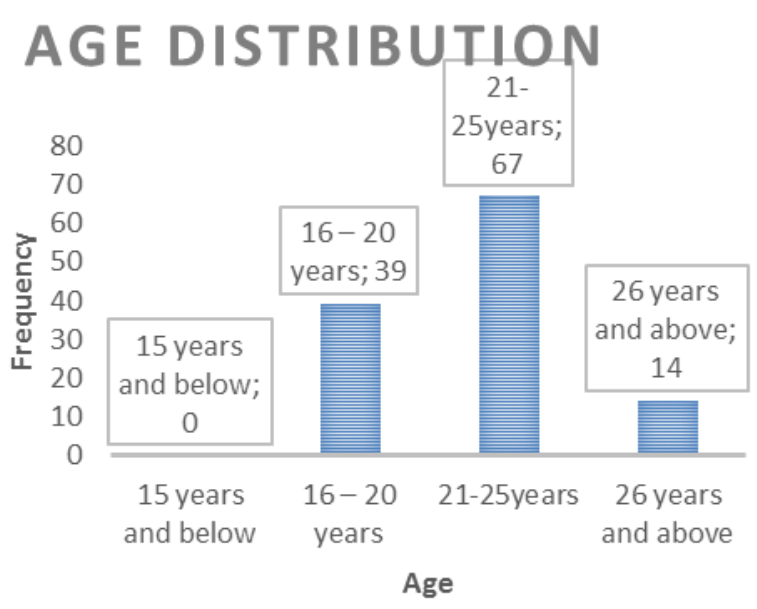

Chart 2. Age Distribution of Respondents

Source: Field Survey (April 2020)

Table 2 and Chart 2 shown age distribution of respondents. There is no respondent that falls between age bracket of 15 years and below. There was total number of 39 students that falls between the age of $16-20$ years, 67 students fall between the age bracket of $21-25$ years and also total number of 16 students fall between age bracket of 26 years and above. The result reveals that the larger number of students are within the age bracket of 21 to 26 years.

Hypothesis 1: There is wide ratio between population of students offering computer courses in KWCOED Oro and number of their lecturers.

Table 3. Lecturer to Student Ratio in the Teaching and Learning of Computer Courses in Kwara State College of Education Oro

\begin{tabular}{|l|l|l|l|}
\hline S/N & Item Statement & Agree & Disagree \\
\hline 1. & $\begin{array}{l}\text { The number of students per } \\
\text { class in Computer Classes } \\
\text { in Kwara State College of } \\
\text { Education Oro is more than } \\
\text { the normal student a class } \\
\text { should contain }\end{array}$ & 94 & 26 \\
\hline 2. & $\begin{array}{l}\text { Numbers of student to lab } \\
\text { attendants in teaching and } \\
\text { learning computer practical } \\
\text { classes are low in } \\
\text { KWCOED Oro }\end{array}$ & 88 & 32 \\
\hline 3. & $\begin{array}{l}\text { Number of student to } \\
\text { lecturers in teaching theory } \\
\text { classes are too high }\end{array}$ & 92 & 28 \\
\hline 4. & $\begin{array}{l}\text { Students are increasing } \\
\text { while there is little or no } \\
\text { increase in computer staff } \\
\text { in Kwara State College of } \\
\text { Education Oro. }\end{array}$ & 64 & 56 \\
\hline
\end{tabular}

Source: Field Survey (April 2020) 
Table 3 data was used to test hypothesis 1 with the use of Chi square. The Chi square calculated value is 23.16 while the Chi square table value at 0.05 level of significance is 7.82 . Since the Chi square calculated is greater than Chi square table, the research hypothesis is ACCEPTED. This means that There is wide ratio between population of students offering computer courses in KWCOED Oro and number of their lecturers. The number of students per class much more than the teacher to student ratio of 1:20 standard by National Commission of Colleges of Education (NCCE).

Hypothesis 2: Overpopulated computer courses lecture room has significant impact on academic performance of students.

Table 4. The Impact of Overpopulation on the Academic Performance of Students

\begin{tabular}{|c|c|c|c|}
\hline S/N & Item Statement & Agree & Disagree \\
\hline 1 & $\begin{array}{c}\text { The resources available for } \\
\text { practical classes is } \\
\text { sufficient }\end{array}$ & 43 & 77 \\
\hline 2 & $\begin{array}{c}\text { high populated class does } \\
\text { not disturb hearing lecturer }\end{array}$ & 24 & 96 \\
\hline 3 & $\begin{array}{c}\text { high populated class } \\
\text { promotes examination } \\
\text { malpractice. }\end{array}$ & 38 & 82 \\
\hline 4 & $\begin{array}{c}\text { Increase in students' } \\
\text { population encourages } \\
\text { good student-teacher } \\
\text { relationship }\end{array}$ & 26 & 94 \\
\hline 5 & $\begin{array}{c}\text { overpopulated classes } \\
\text { contributed to decline in } \\
\text { students health condition }\end{array}$ & 103 & 17 \\
\hline \multicolumn{2}{|c|}{ Sour Fied Survey (Aprit } \\
\hline
\end{tabular}

Source: Field Survey (April 2020)

Table 4 data was used to test hypothesis 2 with the use of Chi square. The X2 calculated value is 147.23 while the $\mathrm{X} 2$ table value at 0.05 level of significance is 9.49 . It was shown that X2 calculated is greater than X2 table, the research hypothesis is ACCEPTED. The implication is that overpopulated computer courses lecture room has significant negative impact on academic performance of students.

Hypothesis 3: Controlling Computer Students Population has influence in Kwara State College of Education Oro. 
Table 5. Controlling Computer Students Population in Kwara State College of Education Oro

\begin{tabular}{|l|l|l|l|}
\hline S/N & Item Statement & Agree & Disagree \\
\hline 1. & $\begin{array}{l}\text { The school should not } \\
\text { admit students more } \\
\text { than their computer } \\
\text { department facility can } \\
\text { accommodate }\end{array}$ & 98 & 22 \\
\hline 2. & $\begin{array}{l}\text { There is need for } \\
\text { increase in staff of the } \\
\text { computer department }\end{array}$ & 120 & 0 \\
\hline 3. & $\begin{array}{l}\text { There is need for } \\
\text { upgrading facilities in } \\
\text { computer lab of the } \\
\text { school. }\end{array}$ & 50 & 70 \\
\hline 4. & $\begin{array}{l}\text { More classes are } \\
\text { needed to be built to } \\
\text { handle over population } \\
\text { in class as there are no } \\
\text { enough classrooms }\end{array}$ & 68 & 52 \\
\hline
\end{tabular}

Source: Field Survey (April 2020)

Table 5 data was used to test hypothesis 3 with the use of Chi square. The $X^{2}$ calculated value is 115.23 while the $\mathrm{X}^{2}$ table value at 0.05 level of significance is 7.82 . It was shown that $\mathrm{X}^{2}$ calculated is greater than $\mathrm{X}^{2}$ table, the research hypothesis is ACCEPTED. The result of this is that Controlling Computer Students Population has influence in Kwara State College of Education Oro.

\section{Conclusion}

The study revealed that the populations of female students are more than the population of male students in Kwara State College of Education Oro. There is no respondent that falls between age bracket of 15 years and below, 39 students fall between the age of $16-20$ years, 67 students fall between the age bracket of $21-25$ years and also total number of 16 students fall between age bracket of 26 years and above. The three alternative hypotheses tested were accepted. The consequences of high population in teaching and learning of computer courses in kwara state college of education oro were revealed. The study revealed that there is wide ratio between population of students offering computer courses in KWCOED Oro and number of their lecturers, overpopulated computer courses lecture room has significant negative impact on academic performance of students and controlling computer students' population has much influence in Kwara State College of Education Oro.

\section{References}

Abimbola, S. B. (2005). Research Methodology and Staticties. Awka: Nuel centi Publishers. Adesina, S. (2000). Students and examination, Ibadan, Adeogun Publisher.

Agu, I. N. (2007). Fundamental of Educational Measurement and Evaluation Ummalma: Cape publisher International limited. 
Dr. Banji, K. (2005). Concept of Population in Nigeria Secondary Schools. Antte press Ilorin.

Earthman, A. S. (2002). Large overpopulated cities in the under developed world. New York: Oxford University.

Green, T. C. and Doran, G. O. (2000). Education management Concept of high population in class point hand courtan Bengraty Co.

Hussein, H. and Mayor, (2019). Overcrowding in Schools: Why is it a Huge Issue? Problems created and proposed solutions. Patch Media

Johnson, R. C. (1995). Introduction to Social Science: New York. John Wilkey and sons.

Kamel, Nevine (April 6, 2019). Overpopulation in Egypt can destroy economic progress: World Bank. Retrieved Saturday August 8, 2020 from Daily News Egypt, Independent Newspaper in English.

Khan, S. G. and lqbal, J. S. (2012). Educational Research process made easy. Owerw: chimas hop publishers.

LeBlanc Rick (2018). The Environmental Impacts of Overpopulation Updated August 31, 2018.

Olaleye, F. O., Ajayi, A., Oyebola, O. B. and Ajayi, O. A. (2017). Impact of Overcrowded Classroom on Academic Performance of Students in Selected Public Secondary Schools in Surelere Local Government of Lagos State, Nigeria. International Journal of Higher Education and Research. 7(1): 110-132.

Oludare, J. O (2003). Academic Develop of Overpopulation in Tertiary Institution Lagos: Caltop publication.

Osuji, J. O. (2008). Effects of Overpopulation on the Academic Performance of Students in Government Secondary Schools in Owerri Municipal Council Of Imo State. www.projectsxtra.com2020

Population and Education - Social and Economic Factors, Conclusions - Fertility, Children, Rate, and Growth - StateUniversity.com.

https://education.stateuniversity.com/pages/2327/Population-

Education.htm\#ixzz6UVHf2b00 Retrieved 07-08-2020.

Siregar, Mohd. Najmi Adlani, Mesiono and Salamuddin (2020). Teacher PAI Learning Strategy in Improving Self Control Students in Binjai State 4 High School. Britain International of Linguistics, Arts and Education. Vol 2 No 2. https://doi.org/10.33258/biolae.v2i2.269

Tanjung, Bahdin Nur, (2020). Human Resources (HR) in Education Management. Budapest International Research and Critics in Linguistics and Education (BirLE) Journal. Vol 3, No 2. ISSN : 2655-1470 (Online).

Tanwa, K. K. (2007). History of education Ibadan: Mac angel publishers. 